\title{
Methods for phenotypic evaluation of crustose lichens with emphasis on Teloschistaceae
}

\author{
JAN VONDRÁK \\ IVAN FROLOV \\ ULF ARUP \\ ALEXANDER KHODOSOVTSEV
}

\begin{abstract}
ВОНДРАК Я., ФРОЛОВ І., АРУП У., ХоДОСОВЦЕВ О.Є. (2013). Методи оцінки фенотипу накипних лишайників на прикладі Teloschistaceae. Чорноморськ. бот. ж., 9 (3): $382-405$.
\end{abstract}

\begin{abstract}
Представлені методи опису фенотипу накипних лишайників, що підвищують ймовірність поділу фенотипічних близьких таксонів на основі анатомічних $\mathrm{i}$ морфологічних ознак (без використання молекулярних даних). Головна ідея методики полягає в найбільш повній і відтворній оцінці ознак фенотипу. Запропоновано список приблизно 100 ознак i стандартизовані способи ї вимірювання. Наводиться глосарій основних морфологічних і анатомічних термінів. Описано базові правила збору, підготовки та вимірювання матеріалу. Запропонований процес опису фенотипу розділений на два етапи: (1) попереднє дослідження проводиться на обмеженому числі зразків, у яких оцінюються всі можливі ознаки; (2) подальше детальне дослідження великої кількості зразків, яке включає опис лише потенційно діагностичних ознак, обраних за результатами попереднього дослідження, виходячи з їх діагностичної значущості.
\end{abstract}

Ключові слова: оцінка характеру, анатомія та морфологія лишайників, опис фенотипу, стандартизаиія

Vondrák J., Frolov I., Arup U., Khodosovtsev A. (2013). Methods for phenotypic evaluation of crustose lichens with emphasis on Teloschistaceae. Chornomors' $k$. bot. z., 9 (3): 382-405.

We present methods for phenotype evaluation of crustose lichens, which enhances the chances to identify highly similar taxa using anatomical and morphological features. The basic idea is to evaluate characters with regard to completeness and reproducibility. We composed a list of about 100 basic characters and propose standardized ways of measuring them. We also present a list of morphological and anatomical terms with their standardized meaning. Basic guidelines for collecting, preparing and measuring lichen material are described. The proposed phenotypic evaluation process has two levels: (1) a pilot study is carried out on a restricted number of samples, but all available characters are evaluated; (2) a detailed study of a large number of samples that includes only potentially diagnostic features that are chosen from the pilot study according to their discriminatory weight.

Keywords: character evaluation, lichen anatomy, morphology, phenotype description, standardization

ВОНДРАК Я., ФРОЛОв И., АРУП У., ХОДОСОвцев А.Е. (2013). Методы оценки фенотипа накипных лишайников на примере семейства Teloschistaceae. Черноморск. бот. ж., 9 (3): 382-405.

Представлены методы описания фенотипа накипных лишайников, повышающие вероятность разделения фенотипических близких таксонов на основе анатомических и морфологических признаков (без использования молекулярных данных). Главная идея методики заключается в как можно более полной и воспроизводимой оценке признаков фенотипа. Мы предлагаем список примерно 100 признаков и стандартизированные способы их измерения. Приводится глоссарий основных морфологических и анатомических терминов.

(C) J. Vondrák, I. Frolov, U. Arup, A. Khodosovtsev

Чорноморськ. бот. ж., 9 (3): 382-405. 
Описаны базовые правила сбора, подготовки и измерения материала. Предлагаемый процес описания фенотипа разделен на два этапа: (1) предварительное исследование проводится на ограниченном числе образцов, у которых оцениваются все возможные признаки; (2) детальное исследование большого количества образцов, которое включает описание только потенциально диагностических признаков, выбранных по результатам предварительного исследовани, исходя из их диагностической значимости.

Ключевые слова: оценка признака, анатомия и морфология литайников, описание фенотипа, стандартизация

\section{Introduction}

It is remarkable that, although the morphology and anatomy of lichens has been studied for over two hundred years, rather little attention has been paid to methodology. Morphological descriptions by some modern authors differ little from those made by lichenologists in the 19th century. These traditional descriptions are often incomplete (some characters are not considered), inadequate (e.g. the precise status of measurements is not specified) and not readily reproducible (methods and terminology not fully specified). There are a few studies in which methods are discussed in detail [EKMAN, 1996; PRINTZEN, 1995], but they are unusual.

One unfortunate consequence of this lack of attention to details can be unjustified claims that two phylospecies cannot be distinguished by their phenotype. However, careful phenotypic evaluations can sometimes distinguish such species. Indeed, in a species-rich and taxonomically difficult group like Teloschistaceae, lack of attention to detail is likely to lead only to taxonomic confusion.

In the course of our work on crustose lichens in the Teloschistaceae, it became apparent that there was a need for some standardization of methods in the morphological investigations of these lichens. We have designed such a standard approach, and it is described below. Our priorities were to ensure completeness (all meaningful characters should be evaluated) and reproducibility (different workers should obtain similar results from any single specimen). We consider that these goals can be obtained, though at a price: our proposed methods are fairly time-consuming.

Some of our methods may be inapplicable to some other groups of lichens, and some of the comments we make below are not necessarily true for other lichen groups. However, we consider that work on most other groups of lichens would also benefit from some standardization.

The following text first defines some morphological and anatomical terms. (It also lists some synonymous terms that we prefer not to use). This is followed by some basic guidelines, which we consider fundamental. Next, we discuss the proposed methods for sample preparation. Then we discuss the evaluation of particular morphological and anatomical structures, and basic methods for the identification of pigments. Finally we discuss some matters concerning process of study, measurement accounts and databases.

\section{Glossary of morphological and anatomical terms in crustose lichens}

Adnate apothecia: slightly raised above thallus surface and slightly constricted at the base. Algonecral medulla: hyaline, paraplectenchymatous tissue below the algal layer, formed by thin-walled fungal cells among dead algal cells or gaps created after the death of algal cells [fig. 2A in VONDRÁK et al., 2008b].

Alveolate cortex: "false cortex" formed by living isodiametric fungal cells among dead algal cells or gaps after dead algal cells [fig. 1D in VONDRÁK et al. 2009]. (The term phaenocortex means cortical tissue of dead algal and fungal cells [RYAN et al., 2002], but this kind of tissue probably does not occur in crustose Teloschistaceae.) 
Amphithecium: see thalline exciple.

Areoles: thallus units attached to the substrate by the entire lower surface; horizontal outline angular or rounded, \pm isodiametric; areoles may be separated from each other (scattered) or forming small separated groups or they may be adjacent (contiguous areolate thalli). Other definitions and meanings of areoles exist [e.g. TøNSBERG, 1992], but our definition is suitable for studies on the morphology of Teloschistaceae.

Ascospore septum (width): width of cell wall in partition of 1-septate or polarilocular ascospores (figs 4-6); some authors [e.g. WETMORE 1994, 1996] use the term isthmus, but it logically refers to the thin cytoplasmatic channel within the septum. The septum has also been denoted as "equatorial thickening" or "equatorial wall-thickening" [e.g. GAYA 2009, NAVARRO-ROSINÉS 2000] but we think these terms are confusing as it may as well be used for the thick waist occurring in citriform ascospores of the $C$. thallincola group.

Biatorine apothecia: apothecia with well-developed or reduced true exciple, but strongly reduced or lacking thalline exciple (fig. 3). Our understanding of this term follows e.g. WIRTH [1995], but differs from the definition in SMITH et al. [2009]. "Lecideine apothecia" are similar but have black, carbonized exciples [sensu WIRTH, 1995], but this term should probably not be used within Teloschistaceae since we do not know of any species with this kind of margin.

Blastidia: thallus outgrowths containing both algal cells and fungal hyphae; (typically c. 50$100 \mu \mathrm{m}$ wide, i.e. larger than typical soredia but smaller than typical isidia); rounded, upward elongated or irregularly shaped; rarely branched; \pm constricted at base; not aggregated (i.e. not forming structures like soralia); without true cortex, but thin alveolate cortex may be present. This term is sometimes used for isidia with constricted bases [e.g. TøNSBERG, 1992], but our definition is more practical for Teloschistaceae.

Bullate thallus: formed of convex, seemingly inflated areoles with \pm rounded horizontal outline.

Cryptolecanorine apothecia: a lecanorine apothecium with a disk deeply recessed in the thallus surface and an indistinct thalline rim barely differentiated from the surrounding thallus as a low bulge; in the strict sense this term only applies to immersed lecanorine apothecia but these are frequently not reliably distinguished from immersed lecideine or immersed biatorine apothecia (LIAS glossary: http://glossary.lias.net/wiki/Main Page). We prefer to avoid this unclear term.

Consoredia: formed by two or more regularly rounded soredia in a larger and usually irregularly shaped aggregate where individul soredia have not broken up; similar to blastidia, but originating from soralia together with individual soredia.

Diffuse (thallus margin): thallus gradually decreasing in thickness towards its margin, usually surrounded by the prothallus.

Epihymenium: the uppermost layer of the hymenium, between tips of asci and tips of paraphyses [fig. 1 in PRINTZEN, 1995]; its width is counted as "hymenium height or thickness - height of asci". (Some authors use the term ep ithecium but it is confusing; see Bungratz 2002.)

Epinecral layer: layer of amorphous organic matter of lichen origin on the cortex surface.

Epithecium: See epihymenium.

Fruticulose thallus: formed of lobes detached from substrate and often erect, or formed of extended and branched isidia. (The definition by RYAN et al. [2002], "dwarf-fruticose thallus, a smaller form of a fruticose thallus", does not reflect the situation in Teloschistaceae, where fruticulose morphotypes are mainly secondarily recruited from crustose lichens.) 
Glutinized cell wall: walls of neighboring cells swollen and conglutinated [fig. 2A, B, in SøCHTING et al., 2002].

Granules (in thallus morphology): vegetative diaspores in crustose thalli resembling globose isidia in shape and size, but the distinction between granules and surrounding surface is less pronounced than in isidia; granules often form the entire thallus; in this case they do not originate from the thallus surface.

Immersed apothecia: not raised above thallus surface.

Isidia: thallus outgrowths, usually more than $100 \mu \mathrm{m}$ wide; usually globose, upward elongated, or peltate, rarely coralloid; covered by a distinct alveolate cortex or true cortex.

Isthmus: the thin cytoplasmatic channel within the septum. (The term has also been used incorrectly to denote ascospore septum.)

Lecanorine apothecia: apothecia with well-developed thalline exciple (fig. 3); true exciple reduced or absent. Most definitions only stress the presence of the thalline margin [e.g. HENSEN, JAHNS, 1974; RYAN et al., 2002; SMITH et al. 2009] and absence of true exciple is suggested. In Teloschistaceae we have not observed apothecia entirely lacking a true exciple, however true exciple is strongly reduced in some groups; we call such apothecia also lecanorine [see fig. 26 in BUNGRATZ, 2002]. Lecanorine margin in immersed apothecia is sometimes called "cryptolecanorine".

Leprose thallus: formed of tiny granules $(<100 \mu \mathrm{m}$ diam), not divided into thallus units. According to LENDEMER et al. [2008], the thallus in a leprose species does not consist of soredia, but of granules.

Lobes: units of crustose thallus with non-isodiametric horizontal outline (fig. 8); usually at thallus margin and elongated outwards from the thallus center.

Medulla: tissue situated below algal layer or below algonecral medulla; usually formed of loose prosoplectenchyma; commonly filled by extracellular crystals of calcium salts.

Paraplectenchyma: tissue (sometimes called "false tissue") formed of \pm isodiametric cells (length / width ratio in most cells $<2$ ).

Parathecium: See true exciple.

Placodioid thallus: rosette-form crustose thallus with lobes at the margin.

Polarilocular ascospores: bicellular with the two cells separated by a thickened, centrally perforated septum (fig. 4).

Proper exciple: See true exciple.

Prosoplectenchyma: tissue (sometimes called "false tissue") formed of cells distinctly longer than wide (length / width ratio in most cells $>2$ ); ideally formed of long and thin hyphae.

Pseudolecanorine apothecia: indistinctly lecanorine, i.e., apothecia that have a poorly developed thalline margin that is often only poorly delimited by a cortex and generally lacks photobiont cells (LIAS glossary: http://glossary.lias.net/wiki/Main Page) We prefer to avoid this indefinite term.

Pycnidial tops: spots on the thallus surface around pycnidial ostioles; these spots often have more intense pigmentation than the surrounding thallus surface; they may also contain different pigments than the surrounding thallus.

Scleroplectenchyma \& scletoprosoplectenchyma: terms used for tissues with thick-walled cells [e.g. RYAN et al., 2002]. We prefer to call them "thick-walled para- and prosoplectenchyma".

Sessile apothecia: raised above thallus surface and distinctly constricted at the base; apothecia with strongly constricted base may be called "sessile with incised base".

Soralia: areas where the surface of the thallus is eroded and where soredia are produced from the algal layer; they are usually well-delimited by surrounding thallus surface. 
Soredia: \pm globose vegetative diaspores containing both algal and fungal cells, produced in groups in soralia from the algal layer; not enclosed in cortex/alveolate cortex; may form groups - consoredia (see above).

Squamules: thallus units detached from substrate at the sides or at least at one side; horizontal outline \pm rounded, isodiametric.

Stalked apothecia: raised above thallus surface, with the base prolonged into the stalk.

Subhymenium: thin layer between hymenium and hypothecium consisting of ascogeneous hy phae [fig. 1 in PRINTZEN, 1995]; we do not recognize this layer in Teloschistaceae.

Suppressed apothecia: slightly raised above thallus surface but not constricted at the base.

Thalline exciple: apothecial margin formed of tissue with fungal and photobiont cells; with or without cortex; (Some authors use the term amphithecium [see fig. 1 in WETMORE, 1994])

Thallus unit: single areole, squamule or lobe.

True exciple: inner apothecial margin formed of tight fungal tissue and lacking photobiont cells. ("proper exciple" or "parathecium" are synonyms for the true exciple.)

Vegetative diaspores (=vegetative propagules): all parts of the thallus, which act as the reproductive units for both fungal and algal partners simultaneously; mainly soredia, blastidia, isidia and granules. (Conidia are not considered here, as they do not contain algal cells.)

Zeorine apothecia: apothecia with both true and thalline exciple (fig. 3); extent of true vs. thalline exciple is sometimes hard to assess externally and must be studied on vertical sections.

\section{Basic guidelines}

(1) Whenever material is collected for a taxonomical study, a rich sample should be taken to include, as far as possible, young as well as well-developed thalli and any aberrant morphotypes (e.g. lichens affected by snail grazing, lichenicolous fungi or trampling). Even if the sample is collected only for identification we would recommend the gathering of a rich sample if possible. Clearly, this rule should not be followed when collecting rare or endangered lichens.
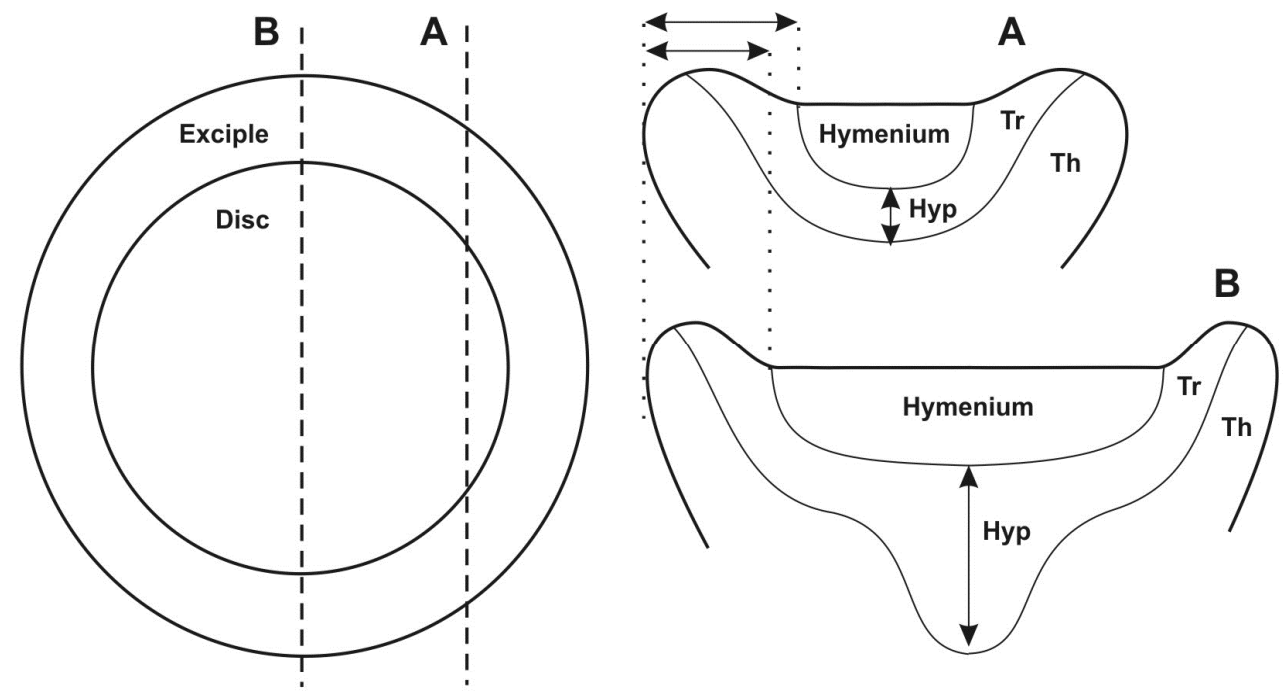

Fig. 1. Left, placements of vertical sections on apothecium viewed from above; right, vertical sections in apothecium; A, vertical section showing incorrect sizes and shapes of exciples, hymenium and hypothecium; B, vertical section through the mid-point showing correct sizes and shapes; Hyp hypothecium; Tr - true exciple; Th - thalline exciple; arrows show measured widths of exciple and heights of hypothecium. 
(2) When collecting material, ecological and geographical characters should be noticed precisely; i.e. locality data, altitude, habitat, substrate (type of bedrock, species of phorophyte, etc.), light conditions, humidity of the micro-site and the exposure to rainwater (see the list of characters in the end of the descriptive part). Adjacent dominant lichens should be also noticed. This kind of information may be as characteristic of a species as details of anatomy and morphology .

(3) In our experience, samples that at first appear to contain only one species sometimes contain two or more taxa with similar phenotypes. Molecular barcoding (ITS sequences are used in Teloschistaceae) should be done at least from anomalous morphotypes in morphologically or anatomically heterogeneous samples. If molecular barcoding is not available, then all \pm homogeneous parts of the heterogeneous samples should be evaluated separately .

(4) Only well-developed and representative material should be used for measurements of phenotype characters. For instance, specimens that are obviously young, suffering from fungal infection or grazed should be omitted. Measurements should not be taken from apothecia without spores or producing only deformed spores, as they are apt to be unreliable. In other words, apothecial characters should be measured only from apothecia containing well-developed ascospores. Apothecial characters may be roughly appraised from apothecia without well-developed spores, but these observations are of limited value.

(5) Vertical sections should be made through the mid-point of ap othecia when observing and measuring the thickness of hypothecium and hymenium and the width of the thalline exciple and true exciple. The further the section is from the mid-point, the more the measurements will deviate from the value at the mid-point (fig. 1). Sections must be made accurately perpendicular to the disc of the apothecium; this is crucial for reliable observations of apothecial tissues-(true excipular hyphae, paraphyses and asci), which are mostly arranged in that plane.

\section{Fresh material versus herbarium material}

BARAL [1992] prefers the "vital taxonomy" in Ascomycetes; using living (fresh) material for observation of vital characters (e.g. hemiamyloidity, presence of croziers in the subhymenium, ultrastructural characters), which disappear or cannot be observed in dead material. Fresh material may be used also for most of the observations within Teloschistaceae, but we found it more practical to work with "stabilized" herbarium material dried out for at least several months. (1) Tissues in our group do not change as dramatically with age of storage as demonstrated by BARAL [1992]. We have observed only indistinct shrinking of mycobiont cells or expanding of their walls in dead lichens. (2) Fresh material often contains only fresh and vital ascospores, which do not show one of the important characters - the width of septa (see below). (3) Fresh material is available for only a short time, but herbarium material is available for years - this enables reproducibility of phenotype evaluations. It is true that living material is essential for observation of a few characters (e.g. hemiamyloidity, presence of croziers in the subhymenium, ultrastructural characters) which disappear or cannot be observed in dead material [BARAL, 1992], but we feel that the advantages of herbarium material outweigh any disadvantages.

Some characters do change in storage. While fungal cells usually do not change in shape and width of their cell-walls, algal cells strongly fade and somewhat deform (shrink) after some years as their protoplast becomes much smaller. In old material, it may be difficult to distinguish between the real algal layer and tissues without living algal cells (alveolate cortex or algonecral medulla). Oil droplets in the paraphyses may also disappear after some years. The colours of ap othecia and thalli may change in old herbarium material as a result of microbial activity (usually when samples are inadequately stored in places with periodically 
increased humidity). However, when we investigated more than 100 year-old samples from various herbaria, the colours of thalli and apothecia often appeared to be unchanged or only slightly changed.

\section{Evaluation of particular structures}

\section{Tissues}

YOSHIMURA and SHIMADA [1980] recognized eight tissue types, when investigating seven unrelated lichen species. Although GAYA [2009] adopted this classification, it seems to be overcomplicated for morphological evaluations in Teloschistaceae. We propose an alternative simpler classification into four categories based on the shape and the width of cellwalls: (1) paraplectenchyma (of \pm isodiametric cells; most cells with an aspect ratio less than two) with thin cell-walls $(<1 \mu \mathrm{m})$; (2) paraplectenchyma with thick cell-walls $(>1 \mu \mathrm{m})$; (3) prosoplectenchy ma (of long cells, with an aspect ratio more than two; ideally of long and thin hyphae) with thin cell-walls $(<1 \mu \mathrm{m})$; (4) prosoplectenchy ma with thick cell-walls $(>1 \mu \mathrm{m})$. In prosoplectenchymatous tissues, we must further recognize between tissue of irregularly arranged hyphae (intricate type) and tissue of parallely arranged hyphae (palisade type). Globose cells (common in Teloschistaceae) or angular cells (very rare) may be recognized in paraplectenchyma [fig. 17 in RYAN et al., 2002]. Tissues are further classified as loose or dense.

The diameter of a cell is to be understood as including its walls, but not any gelatinous envelope or extracellular crystalline sheet (if present). In tissues with thick-walled cells, the width of cell-walls should be also noted. Cell-walls in thick-walled tissues are often glutinized (see the dictionary) and it can be impossible to recognize the boundaries between the cellwalls of two adjacent cells or hyphae; in this case, the diameter of cells may be measured as the diameter of cell lumina. The cell-wall thickness has been proven to be an important character in some Teloschistaceae [e.g. SøCHTING et al., 2002].

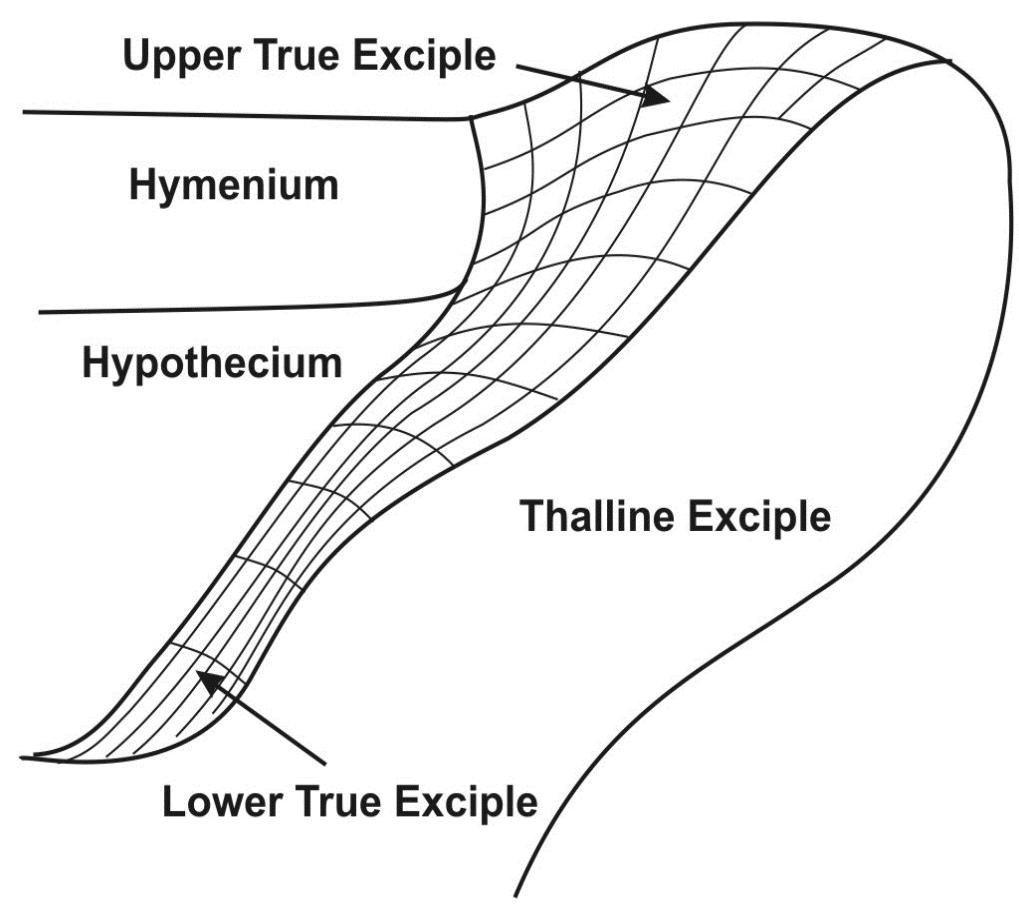

Fig 2. Vertical section of apothecial margin showing variability in cells in the true exciple. 
Gradual transitions between tissue types are not uncommon; e.g. lower part of true exciple is usually prosoplectenchymatous, but its uppermost part is usually almost paraplectenchymatous (fig. 2). The cortex of some Teloschistaceae may be paraplectenchymatous in its upper part and gradually change into prosoplectenchymatous in the lower part. In such complicated situations, both types of tissues should be characterized separately with the note that they grade into each other.

\section{Size and height of apothecia}

The size of the apothecia is considered an important character in some groups of Teloschistaceae [e.g. NAVARRO-ROSINÉS, HLADUN, 1996; VONDRÁK et al., 2012a]. Young apothecia are of \pm the same size in samples of various crustose Teloschistaceae (c. 0,2-0,3 $\mathrm{mm}$ diam.) and the boundary between ap othecial primordia and young apothecia is imprecise. While in some species mature ap othecia stay small $(<0,5 \mathrm{~mm}$ diam.), in others they may grow to large sizes $(>1 \mathrm{~mm})$. Thus we prefer to select larger (mature) apothecia in all examined samples for measurements. Samples without mature apothecia should not be measured. As a practical matter, this can be done simply by excluding samples with apothecia lacking ripe ascospores. The same rule applies to measurements of apothecial height, because young apothecia are usually low and adnate even in lichens in which they are sessile or stipitate when mature.

The height of apothecia is a little used character but it helps in some situations, e.g. Caloplaca ferrugineoides with \pm stipitate apothecia differs from other taxa of the Caloplaca holocarpa group with sessile apothecia [VONDRÁK et al., 2012]. Differences in height of apothecia are also sometimes observed between similar taxa with sessile apothecia, e.g. Caloplaca ferruginea versus $C$. hungarica (our unpublished data). Attachment of apothecia to the thallus is also a notable character; we propose to use six categories [after fig. 5 in FOUCARD, 2001; descriptions in the dictionary above]: (1) immersed in the thallus, (2) suppressed, (3) adnate, (4) sessile, (5) sessile with incised base, (6) stalked apothecium. Such a fine scale may be useful in distinguishing between similar taxa, e.g. Caloplaca variabilis s.lat. (2-5) and C. chalybaea (1-4).

In species with very high apothecia, the medulla may be very high below the apothecial disc [often several times; fig. 3 in STEINER, POELT, 1982]. In this case, height of medulla below apothecia must be measured as a separate character from height of medulla in thallus.

\section{Apothecial disc}

The diameter of the disc need not be measured: it is calculated as "diameter of apothecium - minus widths of (both) margins". The colour of the disc reflects the presence of pigments in the epihymenium or/and presence of a pruina on the disc surface. The colour of the disc and the whole apothecia is strongly influenced by light conditions (e.g. normally orange apothecia are often pale yellow in strong shade), but it is an important diagnostic character in some groups [e.g. SøCHTING et al., 2008]. Apothecia are basically yellow, orange or red (when with anthraquinones) or grey, brown or black (when without anthraquinones), but they may be covered by a pruina, which may be rusty orange, brown, olive or white (in apothecia with anthraquinones) or white (in apothecia without anthraquinones). Anthraquinone containing apothecia may also turn black in some species. The "natural blackening" of apothecia must be distinguished from darkening due to the presence of melanins in cell-walls of lichenicolous fungi (especially hyphomycetes). These, if present, are usually easily seen under the stereomicroscope as dark dots, spots or networks on the apothecial surface. 


\section{True and thalline exciple}

Three basic types of apothecial margins occur in Teloschistaceae: (1) biatorine, (2) lecanorine and (3) zeorine - definitions are in the dictionary above. Characters of the apothecial margins are very important; e.g. lecanorine apothecia are diagnostic for the Caloplaca cerina group [ŠOUN et al., 2011] and biatorine apothecia for e.g. Caloplaca nubigena complex [fig. 5B in WILK, 2012] and C. oleicola [VONDRÁK et al., 2010]. However, most of Teloschistaceae have zeorine apothecial margin, where the ratio of true vs. thalline exciple may vary strongly within a single taxon [e.g. POELT, WUNDER, 1967].

We propose to measure the width of true and thalline exciple in the direction precisely parallel to the main thallus surface (e.g. in a horizontal direction if the thallus is growing on a horizontal substrate; fig. 3, black arrows). It means that the width of the true and thalline exciples gives us the total excipulum width in a natural view from above. The basic rule 5 (above) must be maintained. In some cases, especially when the thalline exciple cannot be veiwed below the true exciple when observed from above, the width of the thalline exciple may be alternatively measured in the direction perpendicular to the outer surface of the exciple, approximately at the mid point of apothecial height (fig.3, grey arrows).

\section{Lecanorine apothecia}
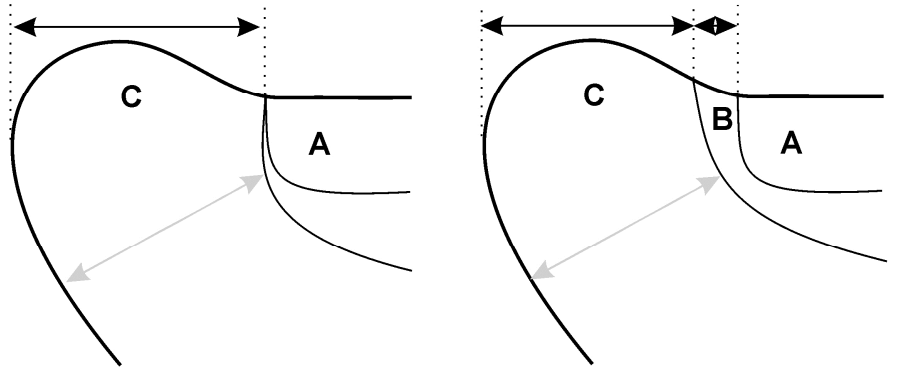

\section{Zeorine apothecia}
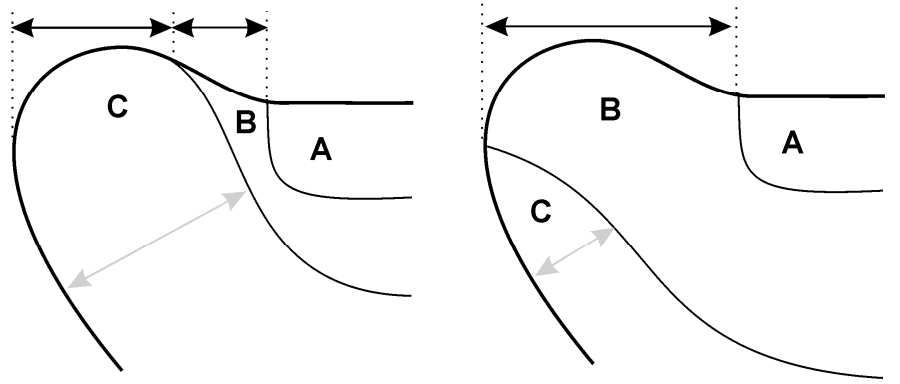

Biatorine apothecia
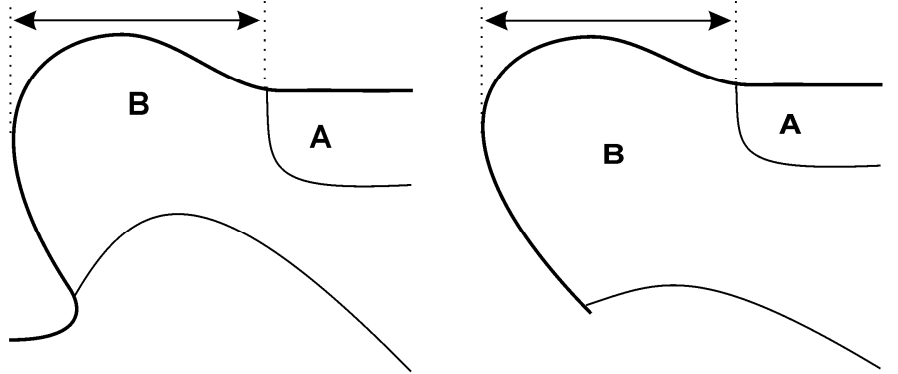

Fig 3. Vertical sections of apothecial margin; variability in lecanorine apothecia (pictures above); in zeorine apothecia (pictures in the middle); in biatorine apothecia (pictures in the bottom); $A=h y m e n i u m ;$ $B=$ true exciple; $C=$ thalline exciple. Black arrows; standardized measurements of widths of true and thalline ex ciples. Grey arrows; alternative possible measurements of the thalline ex ciple (explained in the text). 
The colour of the apothecial margin reflects pigmentation in the uppermost true exciple and the outer thalline exciple. The colour of both types of exciples may differ considerably and should be assessed separately, e.g. in the Caloplaca xerica group [VONDRÁK et al., 2012], the true exciple is in shades of yellow-orange and the thalline exciple is in shades of grey or white pruinose. Both types of exciples in zeorine apothecia have very similar colour in some Teloschistaceae, e.g. the C. citrina group [VONDRÁK et al., 2009], and cannot be clearly distinguished on the surface and the apothecia appear biatorine. In these cases the widths should be measured on vertical sections (not simply assessed in a stereomicroscope).

In the vertical section, zeorine apothecia in Teloschistaceae are more or less similar to fig. 2. The true exciple has rather isodiametric cells in the uppermost part, but its lower parts are formed by palisade prosenchy ma which disappears below the hyp othecium. Some species [e.g. Caloplaca irrubescens, WETMORE, 2003], however, have a true exciple largely formed by paraplectenchyma. The presence or absence of a cortex in the thalline exciple may also provide important information, as well as its width, position, extent and structure when present [e.g. GIRALT et al., 1992; VONDRÁK et al., 2012].

\section{Hymenium and hypothecium}

The height (or thickness) of the hymenium and hy pothecium are usually only used as supporting characters in regional identification keys [e.g. HANSEN et al., 1987; POELT, 1969; SøCHTING et al., 2008; WIRTH, 1995; FLETCHER, LAUNDON, 2009]. Nevertheless, these characters should be noted, because they may be important in particular groups. For measurements of hymenium and hypothecium, the "basic rule 5" (see above) should be maintained. We propose to measure hymenium and hypothecium height in the central, highest part (fig. 1). Apart from the height of the hyp othecium, its shape is also important as it may be flat at the bottom (e.g. in Caloplaca lobulata group) or have a conical shape with the tip facing downwards in the central part (e.g. in Caloplaca xerica group). It should be noted if the hy pothecium fully rests on an algal layer, or if it is connected with the medulla in the central part. Another character employed in some papers [e.g. MUGGIA et al., 2008] is the presence vs. absence of extracellular oil drops in the hymenium or hypothecium (inspersed tissues). Hypothecial tissues are rarely also species specific [paraplectenchyma in C. chalybaea, fig. $8 \mathrm{~A}$ in WILK, 2012].

\section{Paraphyses}

Studies in Teloschistaceae often use the width of (usually clavate) paraphyses tips; it is considered a good character for taxa in some studies [e.g. NAVARRO-ROSINÉS, HLADUN 1996]. POELT [1969], as well as our own studies, suggests that also the width of paraphy ses in the lower part of the hymenium may be a good character. The ratio of "width of paraphyses tip/width of paraphyses in the lower hymenium" may be an even better character. For instance, some species from the Caloplaca variabilis group have thick paraphyses, which broaden only slightly at their tips. The op posite is found in species of e.g. the C.xerica group, which show a larger difference between thinner paraphyses and their widened tips (our unpublished data). The number of widened cells in the paraphyses below their tip s may also differ among taxa [e.g. NAVARRO-ROSINÉS, HLADUN, 1996].

Branching and anastomosing in paraphyses also varies between species [see e.g. NAVARRO-ROSINÉS, HLADUN, 1996]. Our experience is that branching and anastomosing is present in all carefully studied species in Teloschistaceae, though very rare in some samples. The frequency of these features should be noted (perhaps three categories; rare/regular/common). Another noteworthy character is the presence/absence of oil-drops in the upper cells of the paraphyses [e.g. GIRALT et al., 1992]. 
Asci

Asci in crustose Teloschistaceae appear to be consistently of the Teloschistes-type [HONEGGER, 1978]. The shape of the asci is almost always clavate, but some species seem to have more cylindrical asci (Arup, unpublished). The size of the asci correlates with two other characters: ascospore size and height of the hymenium. In our experience, the width and length of asci are strongly dependent on the developmental stage of the ascospores inside. We have also observed increasing of the width of asci by pressure in squash preparations, thus we prefer to avoid measurements of asci in squash preparations. In conclusion, we are skeptical about the value of ascal characters, but they must be considered in pilot studies (explained below).

\section{Ascospores}

Ascospore shape, size and the width of the ascospore septum are commonly used characters in Teloschistaceae, as is apparent from many identification keys [CLAUZADE, ROUX, 1985; FLETCHER, LAUNDON, 2009; NIMIS, 1992; WIRTH, 1995]. Unfortunatelly, ascospores are not measured consistently; some lichenologists investigate still living, immature or overmature ascospores and get unreliable measurements (fig. 4). $\mathrm{KOH}$ pretreatment must be avoided before measurements of ascospore characters, because it causes significant swelling of cell-walls and widening of ascospore septa [e.g. BARAL, 1992; our observations].

Ascospore length and width are important characters on their own, but their ratio also gives some information about shape. The ascospore shape in Teloschistaceae is usually ellipsoid in a broad sense (i.e. almost globose, broadly ellip soid, thinly ellipsoid or fusiform), but occasionally rhomboid or citriform (fig. 6D, E) or other shapes. Note also that the ascospores are not always polarilocular, but exceptionally also simple, 1-, 2- or 3-septate, without thickened septa.
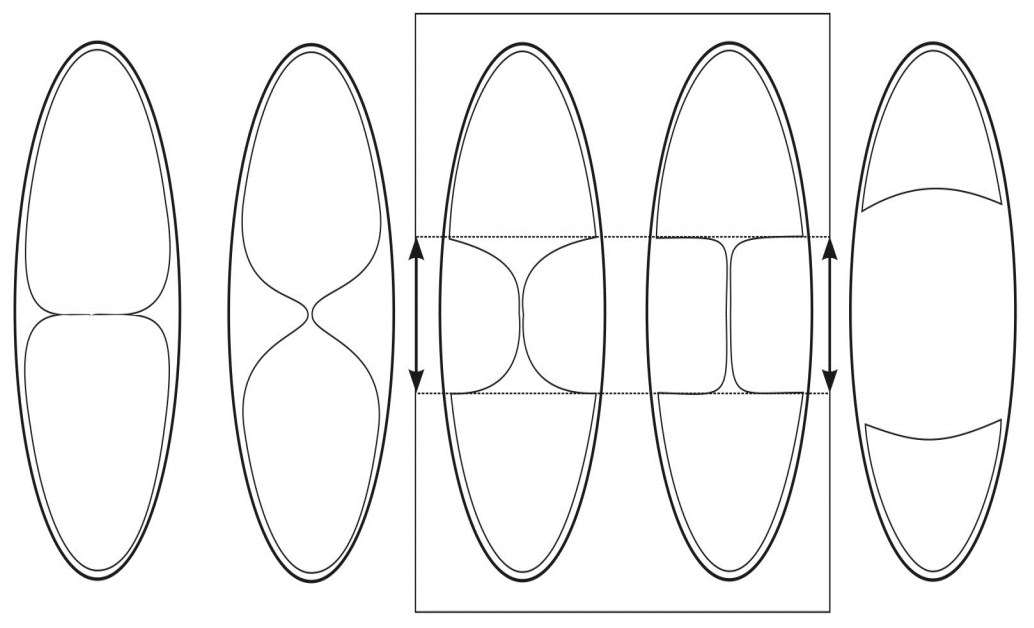

Fig. 4. Development of spores in Caloplaca. In young spores (two on the left side), septum width cannot be clearly defined because of rounded shape of inner spore wall. Only "stabilized" ascospores (those in square) should be measured, because their septum widths are defined by the distance of inner walls of the cells (loculi). Old spores showing strong plasmolysis (the one on the right) without the internal canal between cells should not be measured, because iner cells are getting smaller.

The width of the ascospore septum is a very important character for "rough" identifications of samples, because this character may determine the placement of samples in particular groups or genera. For instance, Caloplaca crenulatella and similar species (Xanthocarpia spp.; [sensu ARUP et al., 2013]) have thin spore septa, but morphologically similar species from the C. holocarpa group (Athallia spp.; [sensu ARUP et al., 2013]) have spores with distinctly thicker septa. Thus, correct measurements of septa are essential. In 
Teloschistaceae the spore septum in fresh spores often looks thin, but in herbarium material, the spores are dead and the septum thickens to vary ing extents in different species. It normally takes about a year of dry storage for spores to die completely (become stabilized) and show the typical Caloplaca type of septum, but it may take as much as two years for all spores to be stabilized in a sample. Thus, in fresh samples the spores have to be killed to show the typical form and septum morphology. Measurements of samples containing only fresh or only old spores (after a strong natural plasmolysis) should not be mixed with correct measurements of dead, stabilized ascospores (fig. 4).
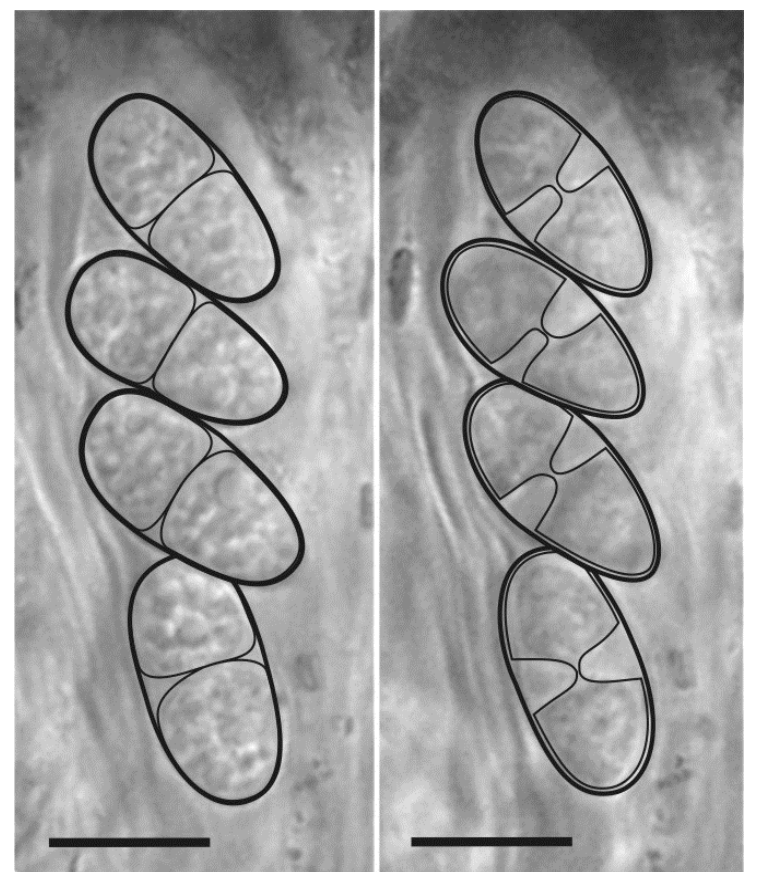

Fig. 5. Young ascospores of Caloplaca interfulgens; left, observed before heating and drying (indistinct wall thickenings at septa); right, after heating and kept for 5 minutes in dry state (wall thickenings at septa well-pronounced); bars $=10 \mu \mathrm{m}$.

Although we propose to avoid measurements of fresh and old ascospores for taxonomic studies, we may sometimes need to identify fresh samples immediately. In such cases, following the simple method proposed by STEINER and PEVELING [1984] and modified by us may be used. Hand-cut sections in microscopic preparations are heated (we heat samples to $100^{\circ}$ for c. 1 second), dried out and left for about 5 minutes in dry state before a second moistening. After this treatment, samples usually show \pm correct septum widths (fig. $5)$.

Outer ascospore wall is usually uniformly thin, but various wall-thickenings are rarely present; e.g. in the sand-glass spores sensu NAVARO-ROSINÉS et al. [2000] and ARUP [2006] or the Physcia-type ascospores with apically thickened walls [e.g. NAVARRO-ROSINÉS, HLADUN, 1992]. Various ascospore shapes are depicted on fig. 6.

\section{Thallus}

The thallus provides a number of useful characters, including: size, thickness, colour and character of its units (areoles, squamules and lobes), though they are often modified by the environment. Measurements should not be made on juvenile or poorly developed thalli. Practically, thalli with well-developed apothecia (in fertile taxa) or well-developed vegetative diaspores (in rarely fertile or sterile taxa) should be used. 

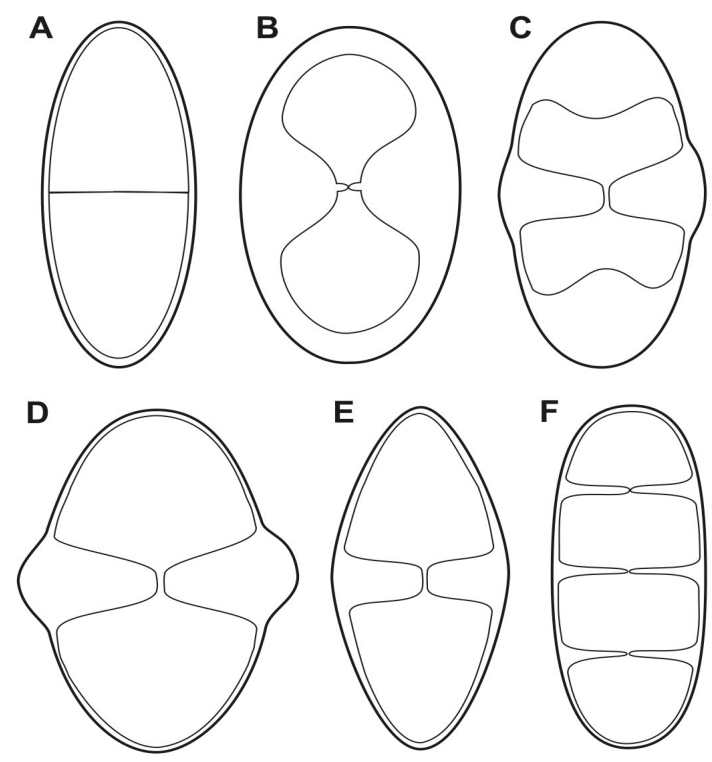

Fig. 6. Unusual ascospore shapes in Teloschistaceae; A, 1-septate without broadened wall in septum area; B, "sand-glass ascospore" with overall broadened wall; C, Rinodina-type; D, citriform; E, rhomboid; F, 4septate.

By the thallus size, we mean the ground area of the thalli, which is usually expressed by the diameter of thallus; this is easy to employ in radially growing lichens. In irregular thalli, we prefer to use a reasonably representative (for instance average) diameter. When thalli with a radial growth pattern grow closely together, they may merge into a large conglomerate. In this case, we propose to measure diameters of only well-circumscribed individual thalli (not conglomerates); as did GAYA [2009] in the Caloplaca saxicola group. Measurements of the thallus diameter are problematic in a few lichens, where the central parts are soon detached and parts of the thallus margin continue to grow forming long and cambered "belts" [e.g. Caloplaca anularis; ClAUZADE, POELT, 1972]. In this case, we propose to measure width and length of the "belts" as characters showing ground area of the thalli. Measurements of thallus size in taxa with consistently poorly developed thalli, with effuse thalli, or with areoles squeezed in between thalli of other species may have little meaning.

Thallus thickness should be measured in well-developed parts of the thallus, i.e. in the area within the studied sample, where the thallus is most representative. Places, where the thallus forms thick tumors or is unusually abruptly swollen, must be avoided. Figure 7A shows that the profile of thickness along a thallus diameter may be different in various lichens. Some lichens are thickest at the centre of the thallus and others at (or near) the margins. The location of the thickest part of the thallus may itself be a noteworthy character. Figure 7 also shows how results may depend on the measurement procedure: random measurements (fig. 7B), or measurements in highest points of well develop ed areoles (fig. 7C; see also localizations of measurements on fig. 7A). Both measurement procedures are possible, but we prefer the latter one, because it has better discrimination power (see the differences between measurement spectra in figs 7B \& 7C).

Old thallus units may be overgrown by younger thallus units (especially in squamulose thalli), so the final thallus may be formed of several layers of thalli covering each other [fig. 1C in VONDRÁK et al., 2008a]; this multiplies the final thallus width. In this case, we recommend measuring the width of uppermost units, even if lower areoles (or squamules /lobes) are still not dead. Nevertheless, overlapping thallus units may be a noteworthy character of some taxa. 
The thallus may be membranaceous (thin and not divided into units), but often consists of units well-circumscribed by crevices or broad depressions in the upper surface. The vertical and horizontal shape of these units classifies them as areoles, squamules or lobes (see definitions). Depending on the character and arrangement of the units, the thallus may be densely to scattered areolate, bullate, squamulose, lobate or fruticulose (see definitions). While the diameter is measured in isodiametric areoles and squamules, length and width are assessed in lobes. For reproducibility and consistency of data, width of lobes may be constantly measured at their base (fig. 8, dark bars) and tips (fig. 8, pale bars). Measurements of lobes is however a difficult topic and methods may have to be modified for particular studies.

The colour of the thallus is largely determined by pigments deposited in the cortical layer, though they may be masked by a crystalline pruina (usually white) deposited on the thallus surface. The thallus may turn darker owing to the presence of melanins in cell-walls of lichenicolous fungi (especially hyphomycetes). They are usually easily detected under the stereomicroscope as dark dots, spots or networks on thallus surface. Grazing by snails causes paler thalli as the pigment itself is eaten or reduced. Thalli with strong fungal infections, grazed or otherwise abnormally affected should not be evaluated at all.

\section{Vegetative diaspores}

The thallus may produce vegetative diaspores, which we divide into isidia, blastidia and soredia (see definition above). Differences between soredia and blastidia and between blastidia and isidia are not always definite but rather continuous. In extreme cases, soredia, consoredia, blastidia, isidia and granules may be found on a single lichen thallus and should be assessed separately. The presence or absence of vegetative diaspores is traditionally used as a diagnostic character for species in Teloschistaceae, modern ap proaches however show that thalli with and without vegetative diaspores may occur in a single species [e.g. LENDEMER, MORSE, 2010, WETMORE, 1994, WIRTH et al., 2011]. When soredia are present, their position, shape and size should be noted, and measurements of soredia and consoredia (see definitions above) should be separated.

\section{Cortex, algal layer, medulla}

The cortical tissue, if present, may have various appearances, when observed in vertical sections. Based on our experience, we outline four categories (fig. 9): (1) even cortex; (2) uneven cortex; (3) cortex with cones; (4) fungal stacks. The cortex with cones is adopted from POELT [1958] [Kögelrinden in original] and the term fungal stacks is proposed by VONDRÁK and KUBÁSEK [2013]. In the first two categories, the thickness of the cortex should be evaluated by random measurements (arrows in figs 9A \& 9B \& grey arrows in fig. 9C), but the height of cortex cones (third category) should be appraised separately (black arrows in fig. 9C). In the fourth category, heights and widths of fungal stacks are measured. The width of fungal stacks often differs in their upper and lower part; we prefer to measure their width at the mid point of their height. A real cortex (see the definition) is not common in crustose Teloschistaceae. In European taxa, a false "alveolate cortex" (see the definition) is more frequent.

An ep inecral layer (see the definition) may cover the cortical layer and its thickness may be of taxonomic importance. The boundary between a living cortical tissue and the epinecral layer is often difficult to recognize, but in our experience dead cells of the epinecral layer are not stained by lactoglycerol-cottonblue. In Pyrenodesmia sensu ARUP et al., 2013 (species related to the black-fruiting Caloplaca variabilis), the boundary is recognized as the thin layer of upper cortex / alveolated cortex containing a grey pigment $(\mathrm{K}+$ slightly violet); $\mathrm{K}$ - epinecral layer (often very high) is located above this line. 


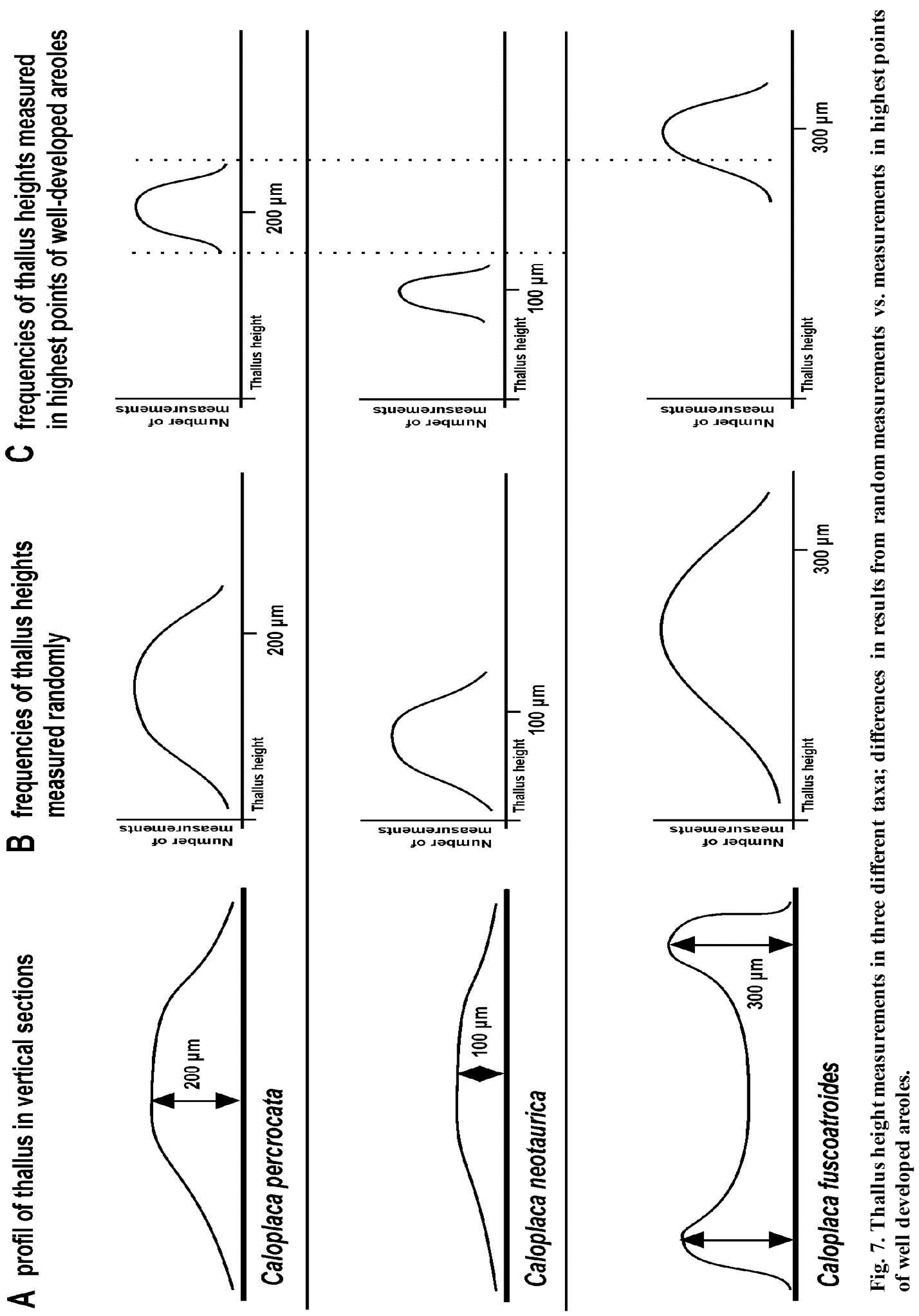




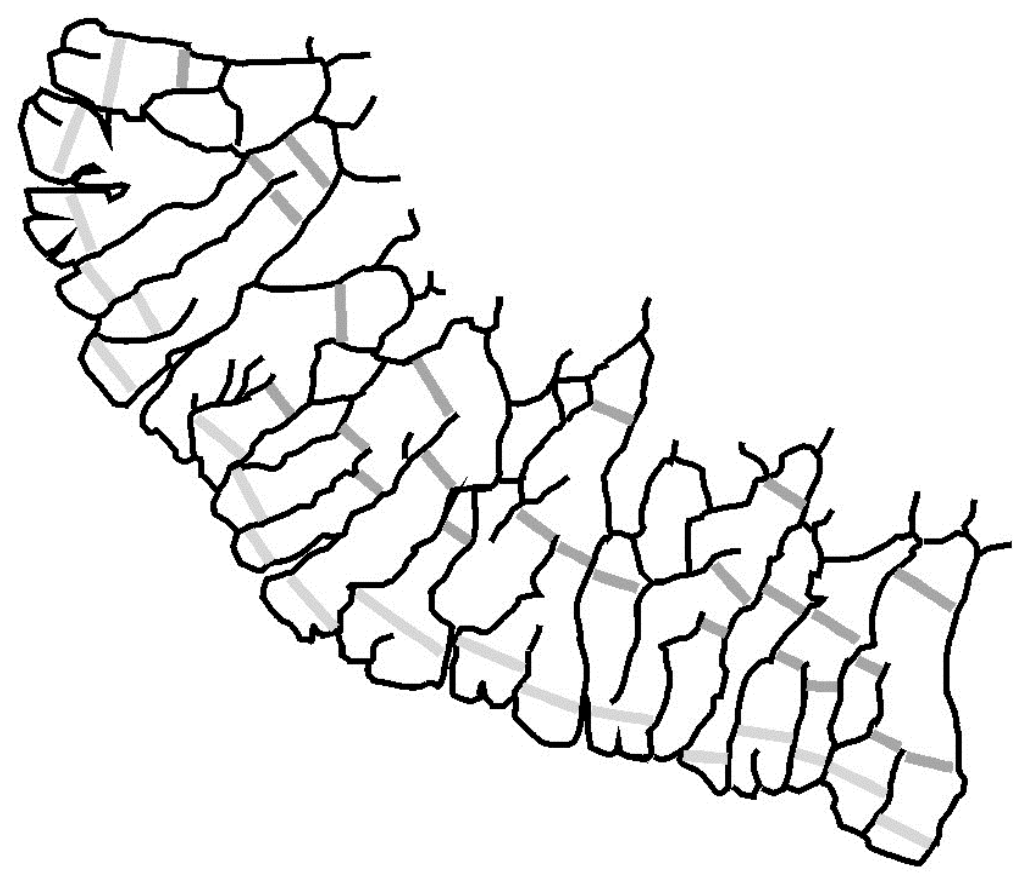

Fig. 8. Outline of marginal lobes in thallus of Caloplaca anularis viewed from above with proposed places of measurements of lobe widths. Dark grey bars - measurements at bases of lobes; pale grey bars measurements at tips of lobes.

The algal layer may form an even horizontal layer, if it is covered by an even cortex or alveolate cortex. At the opposite extreme, it may be formed by stacks [algal stacks sensu VONDRÁK, KUBÁSEK, 2013] enclosed by fungal stacks (fig. 9D). The thickness of the algal layer or the height of algal stacks may be a useful character. The diameter of photobiont cells should be also measured in pilot studies.

Many of the European Teloschistaceae crusts have a thin thallus, so their medulla is inconspicuous, but the medulla is much better developed in thick crusts in arid regions of the world. Its height may be an important character, but the real medulla must be distinguished from the false "algonecral medulla" (see the definition), the height of which is measured as a separate character. The height of the medulla can rarely be measured exactly, because the lower boundary of the lichen surface is often rather vague. (Often the medulla penetrates into the substrate, especially in lichens on calcareous substrata.) The medulla may contain extracellular crystals of calcium salts. Calcium (usually as oxalate or carbonate) is easily detected by the addition of concentrated sulphuric acid, which dissolves the crystals quickly and forms new rosettes of needle-shaped crystals of calcium sulphate [TIMDAL, 1992].

\section{Pycnidia and conidia}

Pycnidia in Teloschistaceae always belong to the Umbilicaria-type or Xanthoria-type sensu VOBIS [1980]. They are formed by one or several chambers opening into a common ostiolum. The size of the pycnidia is hard to assess, because they are hardly visible on the thallus surface and to make a section through the midpoint of a pycnidium is not easy. To get a reasonable measurement of the diameter, the biggest section must be chosen from several consecutive thallus sections made around the presumed centre of the pycnidium. It is often difficult or even impossible to obtain reasonable number of measurements per specimen (see below), but low numbers of measurements give some indication of pycnidium size, which may be a valuable character. The usual diameter is $100-200 \mu \mathrm{m}$, but some species have smaller pycnidia [e.g. Caloplaca pyracea; VONDRÁK et al., 2012a]. 
The colour of the pycnidial tops (see the definition) is an important character. For instance, Caloplaca crenularia has orange-red anthraquinones in their pycnidial tops, whereas the similar $C$. neotaurica lacks these pigments. Both species have otherwise grey thalli without anthraquinones [VONDRÁK et al., 2012b].

Conidiophores (length, branching, etc.) and conidiogeneous cells (size and shape) are variable within Teloschistaceae [fig. 5B-E in ARUP, GRUBE, 1999], but they may also be variable within one pycnidium [fig. 3B in VONDRÁK et al., 2009]. Characters of the conidiophores (height, branching, anastomosing, etc.) as well as the shape and size of conidiogeneous cells may be useful in some groups.

Conidia are usually ellipsoid to bacilliform in crustose Teloschistaceae, but may also be subglobose [VONDRÁK et al., 2008a]. In some taxa, there are both ellipsoid and bacilliform conidia in the same pycnidium.

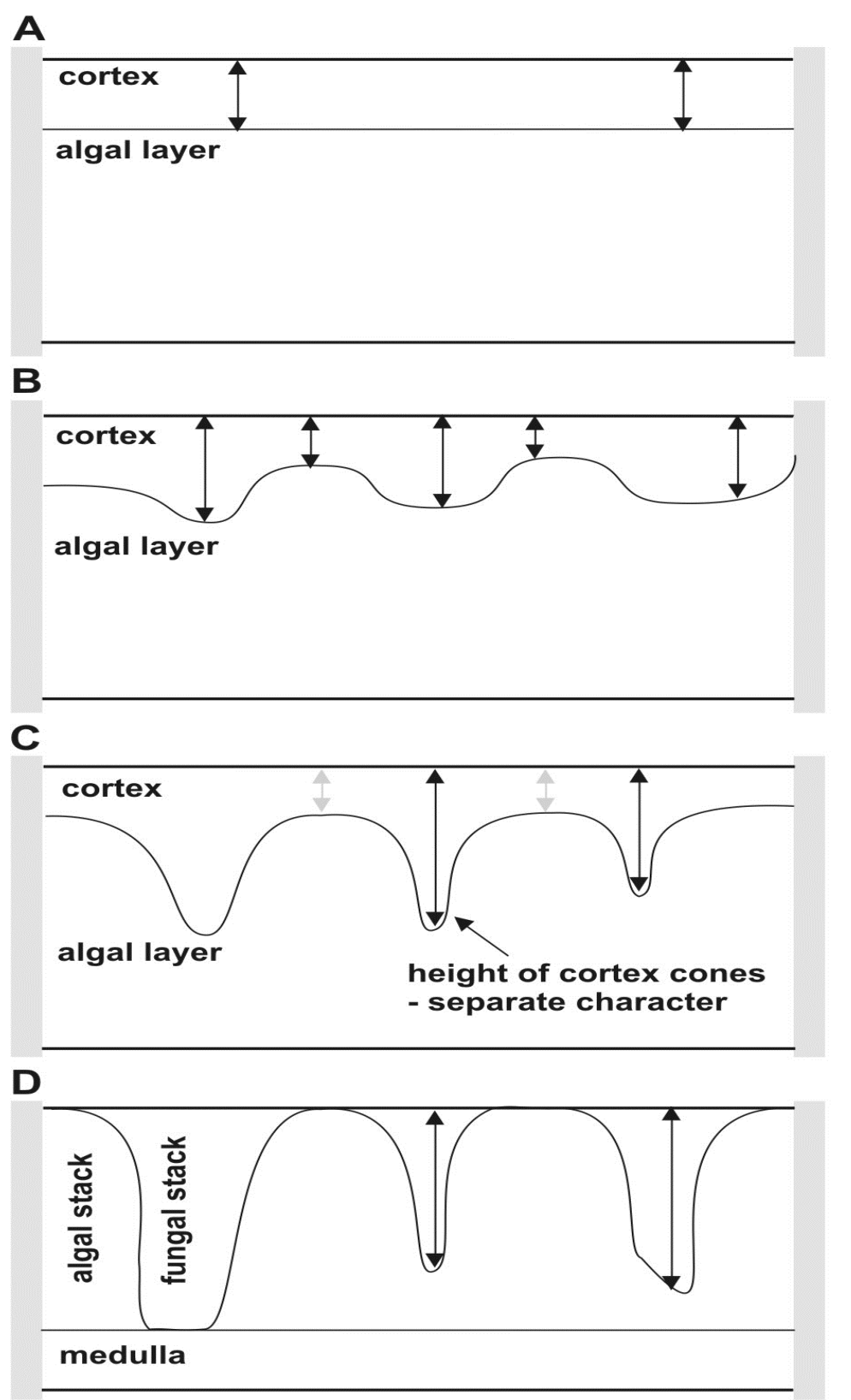

Fig. 9. Types of cortex in vertical thallus sections; A, even cortex; B, uneven cortex; C, cortex with cones; D, fungal stacks. Arrows are feasible positions of measurements (explained in the text). 


\section{Detection of pigments}

\section{Anthraquinones}

The presence of anthraquinones is usually indicated by the yellow to red colour. However, when the amount of anthraquinones is low or their pigmentation is overridden by other pigments (e.g. melanins) the presence of anthraquinones should be tested (e.g. in Caloplaca concilians). These reactions are diagnostic: $\mathrm{K}+$ strongly purple, $\mathrm{K} \rightarrow \mathrm{HCl}+$ yellow, $\mathrm{N}+$ orange, $\mathrm{N} \rightarrow \mathrm{K}+$ violet-blue, $\mathrm{N} \rightarrow \mathrm{K} \rightarrow \mathrm{HCl}+$ yellow, $\mathrm{C}-$ [VONDRÁK et al. 2010]. The first two reactions are normally sufficient.

\section{Presence of chlorinated anthraquinones}

LAUNDON [1992] observed that apothecia of some Caloplaca specimens are C + deep purple, but the reason for this reaction was not certainly known to him. Our experiments showed that the reaction with chloral is a helpful character reflecting the presence $(\mathrm{C}+$ purple $)$ or absence $(\mathrm{C}-)$ of chlorinated anthraquinones. Chlorinated anthraquinones (when present) may be distributed unequally within the lichen surface; usually the lowest amounts are in the thallus, with higher amounts in the apothecium discs and the strongest concentration (strongest $\mathrm{C}+$ reaction) in the true exciple.

When using the C-reaction, care must be taken to use the correct concentration. Chlorinated detergents bought in drugstores are often strongly concentrated and cause a $\mathrm{C}+$ red spot reaction even on samples without chlorinated anthraquinones. Therefore, we strongly recommend testing the negative reaction on apothecia of the common Xanthoria parietina, which never has chlorinated anthraquinones. The concentration of the C-solution must be reduced until it does not cause a red reaction on the apothecial discs of $X$. parietina.

\section{Acetone-insoluble pigments and other pigments}

A list of common acetone-insoluble pigments in lichens is provided by MEYER and PRINTZEN [2000] along with their diagnostic characters. Two of them are present in some Teloschistaceae: Cinereorufa-green (= lecidea green; olive-black, in $\mathrm{K} \pm$ unchanged, $\mathrm{N}+$ $\mathrm{red} /$ purple/violaceous) and Sedifolia-grey (= thalloidima green; greyish, $\mathrm{K}+$ sordid violet, $\mathrm{N}+$ purple/violet). WETMORE [1996] shows the presence/absence of these pigments in the epihymenium, margin and thallus of numerous species. While Sedifolia-grey is commonly present in the European species, Cinereorufa-green is rather rare (e.g. in Caloplaca crenularia, C. exsecuta and C. fuscorufa).

Brown pigments are rarely present in Teloschistaceae crusts: (1) $\mathrm{K}+$ orange pigment [TRETIACH, MUGGIA, 2006], (2) K- pigment [VONDRÁK et al., 2012b] or (3) pigment bleaching and forming colourless needle-like crystals in K (e.g. in Caloplaca demissa; our unpublished data). Other pigments, e.g. the yellow-green usnic acid in Caloplaca (Usnochroma) carphinea, are extremely rare.

\section{Amyloidity}

The reaction of various tissues with I (we use Lugol's solution without any chemical pretreatment) was used as an important character by some authors [e.g. M AGNUSSON, 1944; SøCHTING, 1989]. While the hymenium is perhaps always amyloid, the hypothecium is sometimes amyloid, and ascospores, the true exciple, cortex and medulla may be perhaps amy loid in some cases. Amyloidity is mostly not evaluated by recent authors, but we propose to investigate it in pilot studies (see further down). 


\section{The process of phenotype evaluation}

Since it is often not clear in the beginning which characters could be useful for discrimination of the taxa, phenotype should be evaluated in two steps. (1) A pilot study measuring of all available characters at a restricted number of specimens. This will allow us to evaluate a discrimination power of the characters and select the most powerful of them for the second step. (2) A detailed study - measuring of the selected characters on a large number of samples. The first step acquires samples containing rich and well-developed lichen material (according to the basic rule 1), because mature tissues and well developed structures are needed for thorough observations which are largely destructive. (The chosen specimens must be large enough to avoid destruction of it as it should be possible to evaluate again.) The pilot study is also time-consuming, because more than one hundred characters which are listed below should be considered. In about this step, we propose to investigate at least three geographically distinct samples of each taxon confirmed by molecular analy sis or at least of each putative taxon. Choosing fewer than three specimens per taxon is inadvisable, as it introduces a risk of working with aberrant samples. In each sample, more than five measurements are advisable for each measurable character. Practically it means that at least five apothecia must be destroyed on a single specimen, because hymenium width, hypothecium width and widths of exciples should be logically measured only once per apothecial section (fig. 1; the basic rule 5). We recommend choosing apothecia of variable size and variable extent of the thalline exciple (variability in width of thalline exciple is often visible with the stereomicroscope). Measurements of paraphyses, ascospores and all cell measurements may be done in one section only, but we recommend measuring them in several sections. For thallus characters, more than five measurements are advisable per sample; each measuremen in a separate unit (i.e. areole squamule or lobe).

The time consuming process of the pilot study described above is important for getting preliminary information about (1) the variability of characters within a specimen, (2) the difference in variability among specimens of a single taxon, (3) the difference in variability between or among studied taxa.

Characters for the second step - the detailed study - are selected based on the results from the pilot study. The stepwise linear discrimination analysis (ldc) for ranking the individually best traits could be used for selection of the characters with highest discrimination power. Characters without of with low discrimination power among studied taxa are not considered in the detailed study. At least five measurements of each character on every sample included in the detailed study are advisable. Efforts to select characters based on the pilot study are seen in e.g. EKMAN [1994], but we have not found details about the "pilot study" in the methods part of any taxonomic study on lichens.

In summarizing tables and texts for manuscripts, we recommend showing results of the measurements [following EKMAN, 1996] as (min.-) X1-X2-X3 (-max.), where min/max are extremes from all measurements, $\mathrm{X} 1$ is the lowest specimen arithmetic mean observed, X2 is arithmetic mean of all observations, $\mathrm{X} 3$ is the highest specimen arithmetic mean observed. Total numbers of assessed samples, total number of measurements, and standard deviation from all measurements should be also given for each measured character, e.g. in square parenthesis [n; N; SD].

The following list contains characters, which may be filled into the "working matrix" as follows. Each listed character represents one column of the matrix; the ten measurements in each specimen occupy ten rows. Coding of qualitative characters is explained in the list of characters in square parenthesis. Usual coding is 1 - present, 0 -absent. Some characters are coded by ordinary scale; vegetative diaspores are organized according to their size, colours to 
their intensity, etc. When some character is not evaluated in the respective sample, a symbol different from " 0 " (absence) should be filled in the respective matrix cell. The matrix based on the following list of characters can be universally used for crustose Teloschistaceae, but it is still not complete and may be modified for each studied group.

\section{List of characters for the pilot study}

(1) In apothecia: (1.1) diameter of apothecia; (1.2) height of apothecia; (1.3) attachment of apothecia to thallus [1, immersed; 2, suppressed; 3, adnate; 4, sessile; 5, stalked]; (1.4) shape of disc in mature apothecia [1, concave; 2, flat; 3 , convex]; (1.5) surface of mature ap othecial disc [1, cracked; 0, even]; (1.6) thickness of medulla below disc [measurements are not acquired in groups where the thickness of medulla below ap othecia does not differ from the thickness of surrounding medulla]; (1.7) apothecial margin in mature apothecia [1, persistent, with expanding thalline exciple; 2, persistent, without exp anding thalline exciple; 3, persistent, but reduced; 4, diminishing, subsiding below the disc]; (1.8) width of true exciple; (1.9) width of cells in uppermost true exciple [or diameter in paraplectenchymatous cells]; (1.10) length of cells in uppermost true exciple [in paraplectenchyma not evaluated]; (1.11) width of cell-walls in upper exciple [measurements of cell-wall width are aquired in thick-walled cells, but not in thin-walled cells]; (1.12) width of cells in lower true exciple [diameter in paraplectenchyma]; (1.13) length of cells in lower true exciple [in paraplectenchyma not evaluated]; (1.14) width of cell-walls in lower exciple [measurements of cell-wall width are aquired at thick-walled cells]; (1.15) width of thalline exciple; (1.16) cortex of thalline exciple [1, restricted to lower part; 2 , covering majority of or whole surface]; (1.17) structure of cortex of thalline exciple [1, palisade plectenchyma; 2 , intricate plectenchyma; 3, paraplectenchyma]; (1.18) width of cells in cortex of thalline exciple [diameter in paraplectenchyma]; (1.19) length of cells in cortex of thalline exciple [at paraplectenchyma not evaluated]; (1.20) width of cell-walls in cortex of thalline exciple [measurements of cell-wall width are aquired in thick-walled cells, but not in thin-walled cells]; (1.21) ratio of exciples [1, biatorine apothecia; 2, zeorine apothecia; 3, lecanorine apothecia; 0, ap othecial margin strongly reduced / absent]; (1.22) shape of hypothecium [1, with the central conical extension downward; 0, flat in the bottom]; (1.23) width of hypothecium; (1.24) structure of hypothecium [1, paraplectenchymatous; 2, prosoplectenchymatous; 3, of variable cell shapes and sizes]; (1.25) width of cells in hypothecium [diameter in paraplectenchyma]; (1.26) length of cells in hypothecium [in paraplectenchyma not evaluated]; (1.27) width of cell-walls in hypothecium [measurements of cell-wall width are aquired in thick-walled cells]; (1.28) width of hymenium; (1.29) extracellular crystals in hymenium / hypothecium [1, present; 0, absent]; (1.30) insperse hy menium / hypothecium [1, present; 0 , absent]; (1.31) glutinized hy menium / hypothecium [1, present; 0, absent]; (1.32) width of paraphyses in lower hymenium; (1.33) width of paraphyses tips; (1.34) ratio of $1.30 / 1.29 ;(1.35)$ number of widened cells below paraphyses tips; (1.36) oil drops in upper cells of paraphyses [1, present; 0, absent]; (1.37) branching / anastomosing of paraphyses [1, rare; 2 , regular; 3 , common; 0 , absent $]$; (1.38) height of asci; (1.39) width of asci; (1.40) ascospore length; (1.41) ascospore width (1.42) width of ascospore septa [0, in 1-septate ascospores without broadened wall in partition area]; (1.43) ascospore length / width ratio; (1.44) ratio of septum width / ascospore length; (1.45) ascospores with more than 1 septum [1, present; 0, absent]; (1.46) "sand-glass" type of ascospores [1, present; 0, absent]; (1.47) Physcia-type ascospores [1, present; 0, absent]; (1.48) rhomboid ascospores [1, present; 0 , absent]; (1.49) citriform ascospores [1, present; 0 , absent]; (1.50) more than 8 spores in asci [1, yes; 0 , no]; (1.51) ascospore quality [1, only deformed ascospores present; 2 , well-developed ascospores present; 0 , ascospores absent]. 
(2) in thallus: (2.1) diameter of thallus; (2.2) thickness of thallus; (2.3) vertical complexity of thallus [1, thin membranaceous; 2, leprose; 3, of \pm flat areoles / squamules / lobes; 4, of convex areoles / squamules / lobes; 5 , of highly convex units, distinctly bullate; 6 , fruticulose]; (2.4) thallus units [1, granules only; 2, dispersed areoles; 3, dense areoles; 5, squamules; 6 , lobes; etc.]; (2.5) thallus margin [1, diffuse, with distinct prothallus; 2 , diffuse, without prothallus; 3, areolate; 4, squamulose; 5, lobate]; (2.6) diametre of areoles / squamules / breadth of lobes; (2.7) length of lobes; (2.8) vegetative diaspores [1, granules; 2 , isidia; 3, blastidia; 4, soredia; 0, absent]; (2.9) position of soralia on thallus units [1, on margins; 2, concave on upper surface; 3 , convex on upper surface; etc.]; (2.10) extent of soredia [1, discrete, covering consistently less than 1/4 of thallus units; 2 , discrete, but covering larger area; 3 , confluent, but not covering whole thallus surface; 4 entire sorediate crust]; (2.11) size of soralia; (2.12) size of soredia [diameter]; (2.13) size of consoredia [approximated diameter]; (2.14) size of blastidia [approximated diameter]; (2.15) width or diameter of isidia; (2.16) height of isidia; (2.17) size of granules [approximated diameter]; (2.18) cortex [1, even; 2 , uneven; 3 , cortex with cones; 4, fungal stacks; 0, absent]; (2.19) thickness of cortex / height and width of fungal stacks; (2.20) structure of cortex [1, palisade plectenchyma; 2 , intricate plectenchyma; 3 , paraplectenchyma]; (2.21) thickness of alveolate cortex; (2.22) width of cells in cortex / alveolate cortex [diameter in paraplectenchyma]; (2.23) length of cells in cortex / alveolate cortex [in paraplectenchyma not evaluated]; (2.24) width of cell-walls in cortex / alveolate cortex [measurements of cell-wall width are aquired in thick-walled cells]; (2.25) glutinized cell-walls in cortex [1, present; 0, absent]; (2.26) thickness of ep inecral layer; (2.27) thickness of algal layer / height and width of algal stacks; (2.28) diameter of algal cells; (2.29) thickness of algonecral medulla; (2.30) thickness of medulla; (2.31) medullar tissue [1, loose thin-walled parenchyma; 2, loose thick-walled parenchyma; 3, loose thin-walled prosenchyma; 4, loose thick-walled prosenchyma; etc.]; (2.32) extracellular crystals in medulla [1, present in spots; 2, present all over; 0, absent]; (2.33) size of crystals in medulla; (2.34) extracellular cry stals in cortex [1, present in spots; 2 , present all over; 0, absent]; (2.35) size of cry stals in cortex; (2.36) reaction of crystals with sulphuric acid [1, positive; 0, negative; see more in text above]; (2.37) presence of pycnidia [1, present; 0, absent]; (2.38) width of pycnidia [approximate; min. - max.]; (2.39) width of conidia; (2.40) length of conidia; (2.41) overlapping thallus units [1, present; 0 , absent]; (2.42) presence of pseudocyphaellae [1, poorly developed; 2 , well developed; 3 , absent]; (2.43) lichenicolous thallus [1, young thalli lichenicolous, but mature thalli \pm free-living; 2 , thalli persistently lichenicolous; 0, non-lichenicolous]; (2.44) lichenicolous lichens on studied thalli [1, present (should be specified); 0, absent]; (2.45) lichenicolous fungal infections [1, present (should be specified); 0 , absent].

(3) pigments and colours: (3.1) anthraquinones in ap othecial disc [1, yellow; 2, orange; 3, red; etc.; 0 absent]; (3.2) anthraquinones in true exciple [1, yellow; 2, orange; 3, red; 0 absent]; (3.3) anthraquinones in thalline exciple [1, yellow; 2, orange; etc.; 3, red; 0 absent]; (3.4) anthraquinones in thallus [1, yellow; 2, orange; 3, red; etc.; 0 absent]; (3.5) Sedifoliagrey in apothecial disc [1, grey; 2, blackish; 0, absent]; (3.6) Sedifolia-grey in true exciple [1, grey; 2, blackish; 0, absent]; (3.7) Sedifolia-grey in thalline exciple [1, grey; 2, blackish; 0, absent]; (3.8) Sedifolia-grey in thallus [1, grey; 2, blackish; 0, absent]; (3.9) Cinereorufagreen in apothecial disc [1, grey; 2, blackish; 0, absent]; (3.10) Cinereorufa-green in true exciple [1, grey; 2 , blackish; 0 , absent]; (3.11) Cinereorufa-green in thalline exciple [1, grey; 2, blackish; 0, absent]; (3.12) Cinereorufa-green in thallus [1, grey; 2, blackish; 0, absent]; (3.13) pruina on ap othecial disc [1, white, in spots; 2 , white, covering majority of surface; 3 , olive; 4, rusty; etc.; 0, absent]; (3.14) pruina on true exciple [as in 3.13]; (3.15) pruina on thalline exciple [as in 3.13];(3.16) pruina on thallus [as in 3.13]; (3.17) depigmented (bleached) spots on thallus surface [1, present; 0 , absent $]$; $(3.18)$ chlorinated anthraquinones = positive C-reaction [1, in exciple only; 2 , in disc and exciple; 3 , in disc, exciple and thallus; 0 , 
absent]; (3.19) other pigments in ap othecia [1, present (should be specified); 0 , absent]; (3.20) other pigments in thallus [1, present (should be specified); 0 , absent]; (3.21) pycnidial tops [1, without anthraquinones, not contrasting in colour with surrounding thallus; 2, without anthraquinones, but stronger pigmented than surrounding thallus; 3 , with anthraquinones and not contrasting in colour with surrounding thallus; 4 , with non-chlorinated anthraquinones and brighter colour than surrounding thallus; 5, with chlorinated anthraquinones; etc.]; (3.22) hy pothecium amy loid [1, yes; 0, no]; (3.23) true exciple amyloid [1, yes; 0, no]; (3.24) cortex amy loid [1, yes; 0, no]; (3.25) medulla amy loid [1, yes; 0, no].

(4) distribution and ecology (possible coding for epilithic samples): (4.1) latitude; (4.2) longitude; (4.3) altitude; (4.4.) macro-habitat [1, desert; 2, steppe; 3, forest-steppe; 4, forest; etc.]; (4.5) micro-habitat / substrate [1, epilithic; 0, on other substrate (must be specified)]; (4.6) substrate reaction [1, acidic; 2, intermediate; 3, basic]; (4.7) bedrock type [e.g. 1, calcareous; 0, non-calcareous (should be specified)]; (4.8) substrate stability [1, soil or loess; 2, soft rock; 3, hard but weathered rock; 3, hard rock]; (4.9) substrate particles [1, pebbles; 2, stones, boulders; 3, rock]; (4.10) rainwater exposure [1, sheltered below overhang; 2, on \pm vertical rock face; 3 , on \pm horizontal rock face]; (4.11) local humidity [1, moist; 2 , mesic; 3 , dry (should be specified)]; (4.12) light exposure [1, shaded; 2, partly shaded; 3, open]; (4.13) exposure to cardinal points.

Linda in Arcadia kindly revised the English. Our research was supported by the program NAKI of the Ministry of Culture of the Czech Republic (DF12P01OVV025), the long-term research development project RVO 67985939 and the Grant Agency of Faculty of Environmental Sciences (CULS, 42900/1312/3114).

\section{References}

ARUP U. (2006). A new taxonomy of the Caloplaca citrina group in the Nordic countries, except Iceland. Lichenologist, 38: 1-20.

ARUP U., GRUBE M. (1999). Where does Lecanora demissa (Ascomycota, Lecanorales) belong? Lichenologist, 31: 419-430.

ARUp U., Søchting U., FröDÉN P. (2013). A new taxonomy of the family Teloschistaceae. Nordic Journal of Botany, 31: 16-83.

BARAL H.O. (1992). Vital versus herbarium taxonomy: morphological differences between living and dead cells of ascomycetes, and their taxonomic implications. Mycotaxon, 44: 333-390.

BungarTz F. (2002). Morphology and anatomy of the fertile structures. In Lichen Flora of the Greater Sonoran Desert Region. I. (T.H. Nash III, B.D. Ryan, C. Gries \& F. Bungartz, eds): 24-35. Tempe: Lichens Unlimited, Arizona State University.

Clauzade G., Roux C. (1985) Likenoj de Okcidenta Europo. Ilustrita determinlibro [Lichens of the Western Europe]. Bulletin de la Société Botanique du Centre-Ouest, Nouvelle Série, Numéro Spécial, 7: 1-893.

Clauzade G., Poelt J. (1972). Caloplaca anularis, eine neue Flechte aus den Westalpen. Herzogia, 2: 305-311.

EKMAN S. (1994). Biatora meiocarpa (Nyl.) Arnold, a misunderstood species. Lichenologist, 26: 31-37.

EKMAN S. (1996). The corticolous and lignicolous species of Bacidia and Bacidina in North America. Opera Botanica, 127: 1-148.

Fletcher A., Laundon J. R. (2009). Caloplaca. In The Lichens of Great Britain and Ireland. (C.W. Smith, A. Aptroot, B.J. Coppins, A. Fletcher, O.L. Gilbert, P.W. James \& P.A. Wolseley, eds): 245-273. London: British Lichen Society.

FOUCARD T. (2001). Svenska Skorplavar [Lichen flora of Sweden]. Stockholm: Interpublishing. [in Swedish]

GAYA E. (2009). Taxonomical Revision of the Caloplaca saxicola Group (Teloschistaceae, Lichen-forming Ascomycota). Bibliotheca Lichenologica, 101: 1-191.

Giralt M., Nimis P.L., Poelt J. (1992). Studien über den Formenkreis von Caloplaca flavorubescens in Europa. Cryptogamie, Bryologie-Lichénologie, 13: 261-273.

Hansen E.S., Poelt J., Søchting U. (1987). Die Flechtengattung Caloplaca in Gronland. Meddelelser om Gronland, Bioscience, 25: 1-52.

Henssen A., JAhns H.M. (1974). Lichenes. Stuttgart: Georg Thieme Verlag.

Honegger R. (1978). The ascus apex in lichenized fungi. I. The Lecanora-, Peltigera- and Teloschistes- types. Lichenologist, 10: 47-67.

LAUNDON J.R. (1992). New British species of Caloplaca. Lichenologist, 24: 1-5. 
Lendemer J.C., KNUdSEn K., EliX, J.A. (2008). Lepraria friabilis, a new species from Eastern North America. Opuscula Philolichenum, 5: 77-82.

Lendemer J.C., Morse C.A. (2010). Caloplaca yuchiorum (Teloschistaceae, Lichenized Ascomycota), a new sorediate species from North America. Journal of the Torrey Botanical Society, 137: 327-332.

Magnusson A.H. (1944). Studies in the ferruginea-group of the genus Caloplaca. Kungl. Vetenskaps- och Vitterhets-samhälles Handlingar, Sjätte Följden, ser. B, 3: 3-71.

MeYer B., PRINTZEN C. (2000). Proposal for a standardized nomenclature and characterization of insoluble lichen pigments. Lichenologist, 32: 571-583.

Muggia L., Grube M., Tretiach M. (2008): A combined molecular and morphological approach to species delimitation in black-fruited, endolithic Caloplaca: high genetic and low morphological diversity. Mycological Research, 112: 36-49.

NAvarro-Rosinés P., EgeA J. M., Llimona X. (2000). Caloplaca cancarixiticola, a new species from southeast Spain growing on ultrapotassic rocks. Lichenologist, 32: 129-138.

NAVArro-Rosinés P., GAYA E., RouX C. (2000). Caloplaca calcitrapa sp. nov. (Teloschistaceae) un nuevo liquen saxícolo-calcícola mediterráneo. Bulletin de la Société Linnéenne de Provence, 51: 145-152.

NAvarro-Rosinés P., HLAdun N.L. (1992). Caloplaca latzelii y C. glomerata (Teloschistaceae, Líquenes), dos especies con esporas atípicas. Cryptogamie, Bryologie-Lichénologie, 13: 227-235.

NAVARro-Rosinés P., Hladun N.L. (1996). Les especies saxícolo-calcícolas del grupo de Caloplaca lactea (Teloschistacceae, líquenes), en las regiones mediterranea y medioeuropea. Bulletin de la Société Linéenne de Provence, 47: 139-166.

Nimis P.L. (1992). Chiavi analitiche al genere Caloplaca in Italia (Licheni, Teloschistaceae). Estratto dal Notiziario della Società Lichenologica Italiana, 5: 9-28.

Poelt J. (1969). Bestimmungsschlussel Europaischer Flechten. Lehre: J. Cramer.

Poelt J. (1958). Die lobaten Arten der Flechtengattung Lecanora Ach. sensu ampl. in der Holarktis. Mitt. der Bot. Staatssammlung München, 2: 411-573.

Poelt J., Wunder H. (1967). Über biatorinische und lecanorinische Berandung von Flechtenapothecien untersucht am Beispiel der Caloplaca ferruginea-Gruppe. Bot. Jahrb., 86: 256-265.

PRINTZEN C. (1995). Die Flechtengattung Biatora in Europa. Bibliotheca Lichenologica, 60: 1-275.

RYAN B.D., BUngarTz F., NASH III T.H. (2002). Morphology and anatomy of the lichen thallus. In Lichen Flora of the Greater Sonoran Desert Region. I. (T. H. Nash III, B. D. Ryan, C. Gries \& F. Bungartz, eds): 8-23. Tempe: Lichens Unlimited, Arizona State University.

Seavey F., Seavey J. (2012). Caloplaca lecanorae (Teloschistaceae), a new lichenicolous lichen and several additions to the North American lichenized mycota from Everglades National Park. The Bryologist, 115: $322-328$.

Søchting U. (1989). Lignicolous species of the lichen genus Caloplaca from Svalbard. Opera Botanica, 100: 241-257.

Søchting U., KÄRNEFElT I., KondRATYUK S. (2002). Revision of Xanthomendoza (Teloschistaceae, Lecanorales) based on morphology, anatomy, secondary metabolites and molecular data. Mitteilungen aus dem Institut für Allgemeine Botanik in Hamburg, 30-32: 225-240.

Søchting U., LOREnTSEn L.B., ARUP U. (2008). The lichen genus Caloplaca (Ascomycota, Lecanoromycetes) on Svalbard. Notes and additions. Nova Hedwigia, 87: 69-96.

Šoun J., Vondrák J., Søchting U., HrouzeK P., KhodosovtSeV A., Arup U. (2011). Taxonomy and phylogeny of the Caloplaca cerina group in Europe. Lichenologist, 43: 113-135.

Steiner M., Peveling E. (1984). Lagerungsbedingte Änderungen der Sporenstrucktur bei einigen Arten der Gattung Caloplaca (Lichenes, Teloschistaceae). Beiheft zur Nova Hedwigia, 79: 775-791.

Steiner M., Poelt J. (1982). Caloplaca sect. Xanthoriella, sect. nov.: Untersuchungen uber die "Xanthoria lobulata-Gruppe" (Lichenes, Teloschistaceae). Plant Systematics and Evolution, 140: 151-177.

Timdal E. (1992). A monograph of the genus Toninia (Lecideaceae, Ascomycetes). Opera Botanica, 110: 1137.

TønsBerG T. (1992). The sorediate and isidiate, corticolous, crustose lichens in Norway. Sommerfeltia, 14: 1331.

Tretiach M., Muggia L. (2006). Caloplaca badioreagens, a new calcicolous, endolithic lichen from Italy. Lichenologist, 38: 223-229.

VoBIs G. (1980). Bau und Entwicklung der Flechten-Pycnidien und ihrer Conidien. Bibliotheca Lichenologica, 14: $1-141$.

VONdrÁK J., KhodosovtseV A., ŘíHA P. (2008a). Caloplaca concreticola (Teloschistaceae), a new species from anthropogenic substrata in Eastern Europe. Lichenologist, 40: 97-104.

Vondrák J., Šoun J., Hrouzek P., Ř́íHa P., KubÁsek J., PAlice Z., Søchting U. (2008b). Caloplaca subalpina and C. thracopontica, two new saxicolous species from the Caloplaca cerina group (Teloschistaceae). Lichenologist, 40: 375-386.

Vondrák J., Khodosovtsev A., LŐKÖs L., Merkulova O. (2010). The identity of type specimens in BP of some names in Caloplaca. Mycotaxon, 111: 241-250. 
VondráK J., Khodosovtsev A., Šoun J., VondrÁkovÁ O. (2012a). Two new European species from the heterogeneous Caloplaca holocarpa group (Teloschistaceae). Lichenologist, 44: 73-89.

VONDRÁK J., KUBÁSEK J. (2013). Algal stacks and fungal stacks as adaptations to high light in lichens. Lichenologist, 45 (in press).

Vondrák J., Říha P., Arup U., Søchting U. (2009). The taxonomy of the Caloplaca citrina group (Teloschistaceae) in the Black Sea region; with contributions to the cryptic species concept in lichenology. Lichenologist, 41: 571-604.

VONdRÁK J., Šoun J., VONDRÁKOVÁ O., FrydAy A.M., KHOdOSOVTSEV A., DAVYdOV E. (2012b). Absence of anthraquinone pigments is paraphyletic and a phylogenetically unreliable character in the Teloschistaceae. Lichenologist, 44: 401-418.

Wetmore C.M. (1994). The lichen genus Caloplaca in North and Central America with brown or black apothecia. Mycologia, 86: 813-838.

Wetmore C.M. (1996). The Caloplaca sideritis group in North and Central America. The Bryologist, 99: 292314.

Wetmore C.M. (2003). The Caloplaca squamosa group in North and Central America. The Bryologist, 106: 147-156.

WILK K. (2012). Calcicolous species of the genus Caloplaca in the Polish Western Carpathians. Polish Botanical Studies, 29: 1-91.

WIRTH V. (1995). Die Flechten Baden-Württembergs, Teil 1 \& 2. Stuttgart: Eugen Ulmer GmbH \& Co.

WirTh V., VONDRÁK J., DE BRUYN U., HAUCK M. (2011). Erstnachweise von Flechtenarten für Deutschland und Frankreich. Herzogia, 24: 155-158.

YOSHIMURA I., SHIMADA R. (1980). Fine structures of lichen plectenchymas viewed with the scanning electron microscope. Bulletin of Kochi Gakuen Junior College, 11: 13-28.

Рекомендує до друку

Отримано 26.05.2013 p.

М.Ф. Бойко

\section{Adpeca авторів:}

Я. Вондрак

1) Інститут ботаніки, Академія наук

вул. Замека, 1 CZ-25243, м.Пругоніцее

Чеська Республіка

2) Південнобогемський університет

вул. Бранісовська, 31

м. Чеське Будейовіче, CZ-370 05

Чеська Республіка

3) Факульет вивчення довкілля

Чеський агротехнічний університет

Чеська Республіка

E-mail:j.vondrak@seznam.cz

I. Фролов

1) Південнобогемський університет

вул. Бранісовська, 31

м. Чеське Будейовіце, CZ-370 05

Чеська Республіка

2) Уральський федеральний університет

вул. Мира , 19

Екатеринбург, 620002

Росія

У. Apyn

Ботанічний Музей, Університет Лунда

Бокс 117, 22100 Лунд

Швеція

О. Ходосовиев

Херсонський державний університет

40 років Жовтня, 27

Херсон, 73000

Україна
Authors' addresses:

J. Vondrák

1) Institute of Botany, Academy of Sciences

Zámek 1, Průhonice, CZ-25243

Czech Republic

2) University of South Bohemia

Branišovská 31

České Budějovice, CZ-370 05

Czech Republic.

3)Faculty of Environmental Sciences

Czech University of Life Sciences Prague

Czech Republic

E-mail:j.vondrak@seznam.cz

I. Frolov

1) University of South Bohemia

Branišovská 31, České Budějovice, CZ-370 05

Czech Republic

2) Ural Federal University

ul. Mira 19

Ekaterinburg, 620002

Russia

U. Arup

Botanical Museum, Lund University

Box 117, 22100 Lund

Sweden

A. Khodosovtsev

Kherson State University

40 Rokiv Zhovtnya str. 27

73000 Kherson, Ukraine 